\title{
Low Self-Control, Peer Delinquency and Aggression among Adolescents in Malaysia
}

\author{
Pit-Wan Pung ${ }^{1}$, Siti Nor Yaacob ${ }^{2}$, Rozumah Baharudin ${ }^{2} \&$ Syuhaily Osman $^{1}$ \\ ${ }^{1}$ Faculty of Human Ecology, Universiti Putra Malaysia, Serdang, Malaysia \\ ${ }^{2}$ Family, Adolescent and Child Research Centre of Excellence, Universiti Putra Malaysia, Serdang, Malaysia \\ Correspondence: Pit-Wan Pung, Faculty of Human Ecology, Universiti Putra Malaysia, 43400 UPM Serdang, \\ Selangor, Malaysia. Tel: 60-17-613-6606. E-mail: carinepung@hotmail.com
}

Received: April 16, 2015 Accepted: May 7, 2015 Online Published: July 6, 2015

doi:10.5539/ass.v11n21p193 URL: http://dx.doi.org/10.5539/ass.v11n21p193

\begin{abstract}
The purpose of this study was to examine the relationships between low self-control, peer delinquency and aggression among adolescents. This cross-sectional study was conducted in Selangor, Malaysia among 413 adolescents. The participants were selected from 12 secondary schools by using Multistage Cluster Sampling Technique. Self-Control Scale (Grasmick, Tittle, Bursik, \& Arneklev, 1993), The Peer Delinquency Scale (Loeber, Farrington, Stouthamer-Loeber, \& Van Kammen, 1998) and Aggression Questionnaire (Buss \& Perry, 1992) were used to examine the relationships between adolescents' low self-control, peer delinquency, and aggression. Results showed that there were significant positive relationships between low self-control, peer delinquency and aggression among adolescents. The result also indicated that low self-control has an indirect effect on aggression through peer delinquency. Peer delinquency served as a partial mediator. Low self-control and peer delinquency are important factors in the development of aggression among adolescents.
\end{abstract}

Keywords: low self-control, peer delinquency, aggression, adolescents

\section{Introduction}

Aggression can be defined as any action that intends to harm or injure another living being who intends to avoid such treatment (Shaffer, 2005). Aggression among adolescents is seen as a serious social problem in many societies and it has gained the attention of those in the field of mental health, prevention experts, media and school authorities. Most of the aggression cases occur in school setting (Chapman, 2010; Sagayam \& Wong, 2010; Veera Pandiyan, 2010). The instances of aggression among adolescents include bullying, spreading rumours, hitting and hurting (Michaud, 2009; Sullivan, Farrell, \& Kliewer, 2006; Gottfredson \& Hirschi, 1990).

Social Welfare Department of Malaysia (2013) reported that the number of crimes involving juveniles has increased 30.8\% throughout 2009 to 2013. These figures may indicate that adolescents are becoming more aggressive. Among the crimes committed include possession of weapons, flouting traffic rules, truancy, being involved in criminal activities related to the property of others, gambling, substance abuse, and trespassing prohibited areas.

Past studies (Proctor, 2006; Moretti, Obsuth, Odgers, \& Reebye, 2006; Sheehan \& Watson, 2008) had explored the negative impacts of aggression. Aggression among adolescents might lead to serious negative consequences both to the victims and the aggressors. The victims might experience social rejection as peers might refrain from interacting with them to avoid being threatened by the aggressors. In addition, the victims may develop psychological and personality disorder, experience physical injury and death, show poor academic performance and have bleak future career (Chee-Leong, 2006). Majority of the aggressors are also involved in vandalism, smoking, drinking and fighting (Olweus, 1993 as cited in Chee-Leong, 2006) which clearly violate school rules and regulations, resulting in the aggressors being terminated from school.

Self-control plays a crucial role in influencing the behaviours of adolescents. Past studies (Winstok, 2009; Stuart, 2005; Ezinga, Weerman, Westenberg \& Bijleveld, 2008; Kim, Namkoong, Ku, \& Kim, 2008) found that low level of self-control among adolescents was linked to aggressive behaviour. According to Arneklev, Grasmick, Title and Bursik (1993), people with low level of self-control tend to be impulsive, seek risky activities, and self-centred. Self-control theory claims that low self-control people have characteristics such as impulsive, show 
temper, prefer simpler tasks, engage in risky activities, and are self-centred. These characteristics may lead to involvement in aggression. Conversely, having a high self-control is seen to reduce the probability for adolescents to act aggressively (Grottfredson \& Hirschi, 1990). In short, self-control serves as a mechanism that inhibits formation of negative behaviour as it assists adolescents to resist temptations (Ezinga, Weerman, Westenberg \& Bijleveld, 2008).

The function and importance of peer group are crucial throughout the adolescence period (Harris, 2000; Espelage, 2010). Peers become important for adolescents in terms of socializing with the world outside home (Harris, 2000). Adolescents who experience peer delinquency may behave in an aggressive way (Espelage, Holt, \& Henkel, 2003; Padilla-Walker \& Bean, 2009; Faris \& Ennett, 2012). This is because they tend to behave similar to their delinquent peers in order to gain acceptance and appreciation from them (Eldeleklioglu, 2007). Peer delinquency was also noted to have a major impact on the development of adolescents (Deptula \& Cohen, 2004) as it increases the production of aggressive solutions among adolescents. Adolescents learn to value aggressive solutions positively and they will behave aggressively.

Previous studies found that peer delinquency significantly contributed to adolescents' aggression and peer delinquency is generated by the low self-control. According to Chapper (2005), the role of peer delinquency as a mediator on the relationship between self-control and aggression illustrates that self-control influence adolescents' aggression through peer delinquency. According to the Gottfredson and Hirschi's Self-Control Theory (1990), adolescents with low self-control tend to be more associated with delinquent peers. This is because they are less able to build-up a stable relationship with friends and therefore, they choose to befriend with each other. According to Olson and Hoza (1993), adolescents who have low self-control may have higher chances to experience peer rejection and in turn, they are more likely to associate with the negative peers. Undoubtedly, association with delinquent peers causes adolescents to behave in a negative way such as becoming aggressive (Longshore, Chang, Hsieh, \& Messina, 2004).

Based on this brief overview, this study examined the relationships between low self-control, peer delinquency and aggression among adolescents. In addition, this study examined the mediating role of peer delinquency on the relationship between low self-control and aggression.

\section{Literature Reviews}

\subsection{Self-Control and Aggression}

According to Buker (2011), self-control is treated as a crucial concept in explaining people's behaviour. Baumeister, Heatherton, and Tice (1994) defined self-control as an ability to override and inhibit the undesirable impulse, regulate negative thoughts, emotions and behaviours. Self-control is a conscious effort that could inhibit people from behaving in unacceptable manner (Muraven \& Baumeister, 2000; Eisenberg, Zhou, Spinrad, Valiente, Fabes, \& Liew, 2005; Tangney, Baumeister, \& Boone, 2004). According to Gyurak and Ayduk (2008), individual with high level of self-control could postpone the urge to gain immediate satisfaction and lower the chance to engage in aggressive behaviour.

Gottfredson and Hirschi (1990) claimed that self-control serves as a vital role in the development of negative behaviour among adolescents such as aggression and criminal behaviour. Accordingly, those with low level of self-control have high tendency to behave impulsively and therefore, they are easily engaged in negative behaviour. They are self-centred and prefer simple task. These characteristics may push adolescents toward negative behaviour.

A study of Cheung and Cheung (2008) reported that self-control significantly linked with aggression. Ezinga, Weerman, Westenberg and Bijleveld (2008) aimed to determine the link between self-control (temper, impulsive and adventure) and adolescents' problem behaviours (bullying, finding, and vandalising). The findings revealed that there were significant positive relationships between temper, impulsiveness and adventure with adolescents' problem behaviours. A study conducted in 2010 by Archer, Ferna-Fuertes and Thanzami to examine the correlation between self-control and physical aggression among Indian men revealed that those with high self-control reported lower level of aggression.

Winstok (2009) conducted a study to examine the influence of different types of self-control (adolescents' self-control, urge to control others) on different types of aggression (reactive and proactive aggression). The findings of the study revealed that adolescents with high self-control possessed low level of reactive aggression and adolescents with high level of the need to control others possessed high level of proactive aggression. Denson, Capper, Oaten, Friese and Schofield (2011) conducted a study to examine whether a self-control training session could help adolescents decrease their involvement in aggressive activities. The results revealed 
that adolescents who participated in the training session reported lower level of aggression compared to the other participants who were not involved in the training.

\subsection{Peer Delinquency and Aggression}

According to Steketee (2012), high association with delinquent peers is significantly linked to problem behaviour. The problem behaviours include aggressive behaviour, robbery, dishonesty, and crime (West \& Farrington, 1977). Peer delinquent influences aggression among adolescents can be explained through peer pressure (Pardini, Loeber, \& Stouthamer-Loeber, 2005; Eldeleklioglu, 2007; Padilla-Walker \& Bean, 2009).

Phaik-Gaik, Maria Chong, Habibah and Jegak (2010) found that peer factor significantly influenced antisocial behaviour of adolescents. This study utilized Hirschi's Control Theory to explain how peer factor influences adolescents' antisocial behaviour. During the transition period, adolescents tend to seek social and emotional supports from their peers. Thus, high association with delinquent peers encouraged adolescents to engage in aggressive behaviour. They internalize the negative belief system and attitudes of delinquent peers.

A longitudinal study was conducted by Simons-Morton, Hartos and Haynie (2004) to examine the link between peer delinquency and aggression among adolescents. The findings showed that Time 1 delinquent peers were significantly correlated with Time 1 aggression. In addition, contact with delinquent peers at Time 1 was associated with aggression at Time 2 . The result also showed that peer delinquency at time 2 was linked with aggression at Time 2. The findings indicated that association with delinquent peers significantly influence adolescents' aggression.

According to Platje, Vermeiren, Raine, Doreleijers, Keijsers, Branje, Popma, Van Lier, Koot, Meeus and Jansen (2013), peer delinquency is significantly correlated with adolescents' aggression. The result showed that both of the rule-breaking and aggressive peers had significant correlations with adolescents' aggression.

\subsection{Peer Delinquency as a Mediator}

Chapple (2005) examined the indirect effect of self-control on delinquency through the mediator of peer delinquency. In this study, adolescents' delinquency was measured by combining two components which were violence and property crime. The result reported that adolescents' self-control contributed to peer delinquency affiliation. The study also found that low self-control and peer delinquency significantly contributed to adolescents' delinquency. In addition, the study also noted a partial mediation of peer delinquency on the relationship between self-control and delinquency among adolescents. The study by Chapple (2005) utilized a general theory of crime (Gottfredson \& Hirschi, 1990) to explain how low self-control influences adolescents' association with delinquent peers. This theory claims that children and adolescents with low self-control have difficulties in building healthy friendships. Thus, they tend to find the similar peers with low self-control as their companion.

A study conducted by McGloin and Shermer (2009) aimed to examine the relationships between self-control, peer delinquency, and delinquency among adolescents. In this study, delinquent behaviour was measured by 13 deviant activities which include damage property, run away from home, weapon used and involved in group fight. The findings showed that peer delinquency and self-control independently contributed to delinquency among adolescents. In this study, low self-control was found to have impact on peer delinquency. In addition, this study revealed an important finding that low self-control has indirect influence on adolescents' delinquency through peer delinquency.

Longshore, Chang, Hsieh and Messina (2004) found that adolescents' peer selection was related to self-control, and low self-control has indirect influence on adolescents' deviant behaviour through the deviant peers. In the study of Pulkkinen, Lyyra, and Kokko (2011), the findings showed that high self-control capability positively influences adolescents' social relationship and aggression. Moreover, the result showed that the relationship between high self-control and aggression was partially mediated by positive social relationship. This may indicate that people with high self-control tend to establish positive relationship with others and in turn, they have less involvement in aggressive behaviour. People who have positive social bonding may be less involve in negative behaviours as they do not want to disappoint others.

\section{Methods}

\subsection{Design and the Subjects of the Study}

Correlational research design was utilised in the present study. Structured questions and standardized instruments were used to collect data. The subjects of this study were 413 school-going adolescents aged between 13 and 17 years old in Selangor, Malaysia. The subjects consisted of 186 (45\%) males and 227 (55\%) 
females adolescents. Multistage cluster sampling technique was utilised in this study. This technique has several steps. Step 1) State of Selangor was divided into three zones (North, Centre, and South). Each of these three zones has few districts. 2) Only one district was randomly selected in each zone. The three selected districts were Hulu Selangor, Petaling Utama, and Hulu Langat. 3) From the district, four secondary schools were randomly selected from each district. 4) Only one form was selected from each school. 5) The last step was to randomly select one class from one form. All of the students in the selected class participated in the present study.

\subsection{Instrument}

\subsubsection{Aggression}

Aggression among adolescents was measured by The Aggression Questionnaire developed by Buss and Perry (1992). This questionnaire consists of four subscales with a total of 29 items, rated by a 5 -point scale ( $1=$ strongly disagree, $2=$ disagree, $3=$ somewhere agree and disagree, $4=$ agree, and $5=$ strongly agree). The four subscales are physical aggression, verbal aggression, anger, and hostility. There were two reversed score items. Scores for items were combined to represent aggression scores. The scale score ranged from 29 to 125 . The high scores on aggression questionnaire indicate high aggression among adolescents. In this study, the reliability of this questionnaire was 0.87 .

\subsubsection{Low Self-Control}

Self-control among adolescents was measured by Self-Control Scale which was developed by Grasmick, Tittle, Bursik and Arneklev (1993). This scale has six components with a total of 24 items and rated with a 4-point likert type scale (4=strongly agree, $3=$ agree somewhat, $2=$ disagree somewhat, $1=$ =strongly disagree). The six components are impulsivity, simple task, risk-seeking, physical activities, self-centered and temper. The score for low self-control was calculated by summing up the scores for the 24 items. The total scale score ranged from 24 to 96 . High scores reported on this scale indicate low level of self-control among adolescents. The Cronbach alpha for this scale in the present study was 0.76 .

\subsubsection{Peer Delinquency}

Peer delinquency was measured by Peer Delinquency Scale (PDS) developed by Loeber, Farrington, Stouthamer-Loeber, and Van Kammen (1998). This scale comprised of two components which are delinquency and substance abuse. The present study combined these two components to represent the general scale of peer delinquency. The scale has 15 items and each item can be rated by a 5-point likert type scale (4=all of them, $3=$ most of them, $2=$ half of them, $1=$ few of them, $0=$ none of them). The score for peer delinquency was calculated by summing up the scores for the 15 items. The total scale score ranged from 0 to 60 . High scores on peer delinquency indicate high affiliation with delinquent peers among adolescents. The reliability for PDS in the present study was 0.88 .

\subsection{Data Analysis}

SPSS version 16 was used to analyse data in this study. Descriptive statistic was conducted to analyse respondents' background information. Pearson correlation test was conducted to study the relationships between low self-control, peer delinquency and aggression. A series of simple linear regression was used to test the mediating role of peer delinquency on the relationship between low self-control and aggression.

\section{Results}

\subsection{Personal Background of Respondents}

Table 1 presents the personal background information of respondents which include gender, ethnic, and age. There were $186(45 \%)$ male and 227 (55\%) female adolescents participated in this study. More than half (59.6\%) of the respondents were Malays, followed by Chinese (25.9\%) and Indian (13.1\%). The mean age of respondents was 14.97 ( $\mathrm{S} . \mathrm{D}=1.04)$ and ranged from 13-17 years old.

\subsection{Low Self-Control, Peer Delinquency and Aggression}

Table 2 displays the correlational results for adolescents' low self-control, peer delinquency and aggression. The result showed that there was a significant positive relationship between low self-control $(r=.530, p \leq .001)$ and peer delinquency $(\mathrm{r}=.216, \mathrm{p} \leq .001)$ with aggression. This indicated that adolescents with low self-control tend to be more aggressive. Similarly, those who reported higher affiliation with delinquent peers had higher aggression scores. The result also revealed that there was a significant positive relationship of low self-control with adolescents' peer delinquency $(\mathrm{r}=.229, \mathrm{p} \leq .001)$. The finding implies that adolescents who possessed lower self-control had higher affiliation with delinquent peers. 


\subsection{Peer Delinquency as a Mediator}

Multiple regression analysis was carried out to examine the effect of low self-control on aggression through the mediator of peer delinquency. Then, Sobel test was conducted to confirm the mediating effect of peer delinquency on the relationship. According to Baron and Kenny (1986), few steps must be established before conducting the mediation analysis. The steps are (1) Independent variable (IV) has significant relationship with dependent variable (DV), (2) IV has significantly relationship with mediator, (3) Mediator has significant relationship with DV, (4) Both IV and mediator serves as predictors of the DV. These steps were clearly displayed in Table 3.

Table 1. Personal background information of respondents

\begin{tabular}{ccc}
\hline Variable & $\mathrm{n}$ & $\%$ \\
\hline Gender & 186 & 45 \\
Male & 227 & 55 \\
Female & & \\
Ethnic & 246 & 59.6 \\
Malay & 107 & 25.9 \\
Chinese & 54 & 13.1 \\
Indian & 6 & 1.5 \\
Other & & 2.9 \\
Age & 12 & 46 \\
13 & 190 & 2.2 \\
14 & 9 & 48.7 \\
15 & 201 & 0.2 \\
16 & 1 & \\
17 & & \\
Mean $=14.97$ & & \\
S.D $=1.04$ & & \\
Minimum $=13$ & & \\
Maximum $=17$ & &
\end{tabular}

Note: S.D $=$ Standard Deviation

Multiple regression analysis showed that the low self-control ( $\mathrm{Beta}=.530, \mathrm{SE}=.078, \mathrm{t}=12.664, \mathrm{p} \leq .001)$ and peer delinquency $(\mathrm{Beta}=.120, \mathrm{SE}=1.704, \mathrm{t}=2.830, \mathrm{p} \leq .01)$ independently predicted aggression. Low self-control also significantly predicted peer delinquency (Beta $=.216, \mathrm{SE}=.002, \mathrm{t}=4.478, \mathrm{p} \leq .001$ ) (Table 3 ). Step 4 showed that the beta value for low self-control on aggression (c') after controlling peer delinquency become weaker yet remain significant (Beta $=.504, \mathrm{SE}=.079, \mathrm{t}=11.860, p \leq .001)$. This indicated that both of the low self-control and peer delinquency predicted adolescents' aggression. The result also implied that peer delinquency partially mediated the relationship between low self-control and aggression.

There was $0.216^{*} 0.120=0.026$ indirect size effect found in this mediation result. This implies that aggression is expected to increase by 0.026 units for every one-unit increase in low self-control via peer delinquency. Sobel test supported the partial mediation effect of peer delinquency on this relationship $(\mathrm{z}=2.462, \mathrm{p} \leq .01)$.

Table 2. Relationships between low self-control, peer delinquency and aggression

\begin{tabular}{cccc}
\hline & & $\mathrm{r}$ & \\
\cline { 2 - 4 } & Aggression & Peer Delinquency \\
\hline Low Self-Control & $.530^{* * *}$ & $.229^{* * *}$ \\
Peer Delinquency & $.216^{* * *}$ & \\
\hline
\end{tabular}

Note. ${ }^{* * *} \mathrm{p} \leq .001$

\section{Discussion and Conclusion}

The finding of this study found that low self-control was significantly correlated with aggression among adolescents. The finding is consistent with the previous studies (Gottfredson \& Hirschi, 1990; Pratt \& Cullen, 2000; Yarbrough, Jones, Sullivan, Sellers, \& Cochran, 2012). According to Kemp, Vermulst, Finkenauer, Scholte, Overbeek, Rommes, and Engels (2009), low self-control has consistent association with aggression 
among adolescents. This finding was supported by the self-control theory (Gottfredson \& Hirschi, 1990). This is because adolescents possess the characteristics (simple tasks preference, seek risky activity, prefer physical tasks, and self-centred, impulsive) that prevent them from delaying immediate gratification. A high self-control individual tends to have the strength of inhibition that prevents them from behaving aggressively (Denson, Wall, \& Finkel, 2012).

Table 3. Mediation analysis

\begin{tabular}{lllllll}
\hline Step & IV & DV & B & S.E & Beta & t \\
\hline 1 & Low Self-Control & Aggression & 0.984 & 0.078 & $0.530^{* * *}$ & 12.664 \\
2 & Low Self-Control & Peer Delinquency & 0.010 & 0.002 & $0.216^{* * *}$ & 4.478 \\
3 & Peer Delinquency & Aggression & 9.178 & 1.925 & $0.229^{* * *}$ & 4.767 \\
\hline 4 & Low Self-Control & \multirow{2}{*}{ Aggression } & 0.936 & 0.079 & $0.504^{* * *}$ & 11.860 \\
& Peer Delinquency & & 4.820 & 1.704 & $0.120^{* *}$ & 2.830 \\
\hline
\end{tabular}

Note: $\mathrm{B}=$ Unstandardized coefficient; Beta $=$ Standardized coefficient

$* * \mathrm{p} \leq .01 ; * * * \mathrm{p} \leq .001$

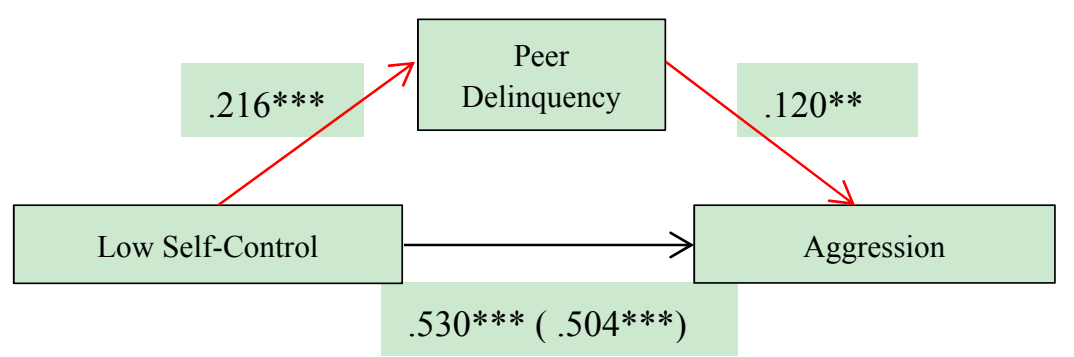

Figure 1. Mediation Model

Peer delinquency had significant correlation with aggression among adolescents. This finding is consistent with the past study of Benson, Tech and Buehler (2012) which found that association with delinquent peer is linked to aggression among adolescents. Association with delinquent peer might cause adolescents to value the negative belief system and eventually involve in behaviour unacceptable by the society (Brechwald \& Prinstein, 2011; Brauer \& Coster, 2015). According to the previous studies (Miller, 2010; Steinberg \& Monahan, 2007; Regnerus, 2002), high peer delinquency will lead to aggressive behaviour because adolescents will act in similar ways to their delinquent peer. These adolescents may experience peer pressure. Peer influence is characterized by the effect of peer-adolescent socialization (Brechwald \& Prinstein, 2011). This view is supported by the Bandura's social learning theory (1986) which suggests that adolescents adopt aggressive behaviours via modelling, social reward and reinforcement from peers. The identity-based theories proposed that adolescents tend to have affiliation with the delinquent peers who have high status. In the process of crystalizing their identity, adolescents might learn to act in similar behaviour as the delinquent peers (Brechwald \& Prinstein, 2011).

According to Baron (2003), the main cause of people's negative problem and social relationship was due to low self-control. The result of correlation analysis in the present study revealed that adolescents' low self-control significantly correlated with peer delinquency. This finding is supported by the past study conducted by Mc Gloin and Shermer (2009) and Hay, Meldrum and Piquero (2013) which found that adolescents' low self-control significantly predicted their peer delinquency experiences. Adolescents with high self-control tend to select peers with similar level of self-control and this friendship is more stable compared to those who adopted low level of self-control (Gottfredson \& Hirschi, 1990).

Self-control theory proposed that the main contributor of people negative behaviour was low self-control. However, other researchers argued that peer factor has similar influence as self-control to the people's negative behaviour (McGloin \& Shermer, 2009). In the study of McGloin and Shermer (2009), it was found that self-control and peer delinquency predicted respondents' delinquency which included aggression activities. Besides, it also revealed that self-control has indirect influence on delinquency through peer delinquency. This indicated that adolescents with low self-control tend to have higher association with delinquent peers and in turn adopted delinquent behaviour. This finding is also supported by Boman and Gibson (2011). The study of Chapple (2015) found that peer delinquency was a partial mediator between self-control and delinquency. Adolescents who are less able to control themselves will choose the similar peer groups. 
The findings of this study demonstrate that low self-control and peer influence are correlated with aggression among adolescents. A conclusion can be made that peer delinquency serves as a mediating variable in explaining how low self-control influence on aggression among adolescents. As discussed earlier, aggression may bring negative consequences on adolescents' various aspects of development. Therefore, the understanding of parents, teachers and community on the causes of aggression become important as it helps to prevent adolescents from engaging in aggressive behaviour. In school, teachers can assist adolescents to identify aggressive behaviour and peer delinquency. Since self-control is treated as a vital factor in adolescents' aggression, school authority is advised to provide better school environment in order to enhance the self-control ability among adolescents. In sum, aggression is treated as a social problem. Therefore, the effective prevention and intervention programme for adolescents' aggression such as counselling, workshops, seminars, and conferences may be implemented to reduce the possibility of adolescents to involve in aggression activities. These prevention and intervention programmes help adolescents to improve their coping skill while facing negative conditions. Besides, the capability of adolescents to regulate their negative emotions and affection will be strengthened and thus prevent them from engaging in aggressive behaviour.

\section{References}

Baron, S. W. (2003). Self-control, social consequences, and criminal behavior: Street youth and the general theory of crime. Journal of Research in Crime and Delinquency, 40(4), 403-425. http://dx.doi.org/10.1177/ 0022427803256071

Baron, R. M., \& Kenny, D. A. (1986). The moderator-mediator variable distinction in social psychological research: Conceptual, strategic, and statistical considerations. Journal of Personality and Social Psychology, 51, 1173-1182. http://dx.doi.org/10.1037/0022-3514.51.6.1173

Baumeister, R. F., Heatherton, T. F., \& Tice, D. M. (1994). Losing control: How and why people fail at self-regulation. San Diego: Academic.

Benson, M. J., Tech, V., \& Buehler, C. (2012). Family process and peer deviance influences on adolescent aggression: Longitudinal effects across early and middle adolescence. Child Development, 83(4), 1213-1228. http://dx.doi.org/10.1111/j.1467-8624.2012.01763.x

Boman, J. H., \& Gibson, C. L. (2011). Does the measurement of peer deviance change the relationship between self-control and deviant behavior? An analysis of friendship pairs. Journal of Criminal Justice, 39, 521-530. http://dx.doi.org/10.1016/j.jcrimjus.2011.10.001

Brauer, J. R., \& Coster, S. D. (2015). Social relationships and delinquency: Revisiting parent and peer influenceduring adolescence. Youth \& Society, 47(3), 374-394. http://dx.doi.org/10.1177/0044118X12467 655

Brechwald, W. A., \& Prinstein, M. J. (2011). Beyond homophily: A decade of advances in understanding peer influence processes. Journal of Research on Adolescence, 21(1), 166-179. http://dx.doi.org/10.1111/j.15327795.2010.00721.x

Buker, H. (2011). Formation of self-control: Grottfredson and Hirschi's general theory of crime and beyond. Aggressive behaviour and Violent Behaviour, 16, 265-276. http://dx.doi.org/10.1016/j.avb.2011.03.005

Buss, A. H., \& Perry, M. (1992). The aggression questionnaire. Journal of Personality and Psychology, 63(3), 452-459. http://dx.doi.org/10.1037/0022-3514.63.3.452

Chapple, C. L. (2005). Self-control, peer relations, and delinquency. Justice Quarterly, 22(1), 89-106. http://dx.doi.org/10.1080/0741882042000333654

Chapman, K. (2010, May 25). Probe on Rawang school with schoolboy gang. The Star. Retrieved from http://thestar.com.my/news/story.asp?file $=/ 2010 / 5 / 25 /$ nation/20100525155802\&sec $=$ nation

Chee-Leong, G. (2006). The psychosocial impact of violence against children. Retrieved from http://www.unicef.org/malaysia/2006.10.19_-_VAC_Msia_Speech_by_Dr_Goh_Chee_Leong.pdf

Denson, T. F., Capper, M. M., Oaten, M., Friese, M., \& Schofield, T. P. (2011). Self-control training decreases aggression in response to provocation in aggressive individuals. Journal of Research in Personality, 45, 252-256. http://dx.doi.org/10.1016/j.jrp.2011.02.001

Denson, T. F., Wall, C. N., \& Finkel, E. J. (2012). Self-control and aggression. Current Directions in Psychological Science, 21(1), 20-25. http://dx.doi.org/10.1177/0963721411429451

Deptula, D. P., \& Cohen, R. (2004). Aggressive, rejected, and delinquent children and adolescents: A comparison 
of their friendships. Aggression and Violent Behaviour, 9, 75-104. http://dx.doi.org/10.1016/S1359-1789(02) 00117-9

Eldeleklioglu, J. (2007). The relationships between aggressiveness, peer pressure and parental attitudes among Turkish high school students. Social Behaviour and Personality, 35(7), 975-986. http://10.2224/sbp.2007. 35.7.975

Eisenberg, N., Zhou, Q., Spinrad, T. L., Valiente, C., Fabes, R. A., \& Liew, J. (2005). Relations among positive parenting, children's effortful control, and externalizing problems: A three-wave longitudinal study. Child Development, 76(5), 1055-1071. http://dx.doi.org/10.1111/j.1467-8624.2005.00897.x

Espelage, D. L. (2010). Bullying in early adolescence: The role of peer group. Retrieved from http://www.athealth.com/Consumer/disorders/bullying.html

Espelage, D. L., Holt, M. K., \& Henkel, R.R. (2003). Examination of peer-group contextual effects on aggressive behaviour during early adolescence. Child development, 74(1), 205-220. http://dx.doi.org/10.1111/14678624.00531

Ezinga, M. A. J., Weerman, F. M., Westenberg, P. M., \& Bijleveld, C. C. J. H. (2008). Early adolescence and delinquency: Levels of psychosocial development and self-control as an explanation of misbehaviour and delinquency. Psychology, Crime \& Law, 14(4), 339-356. http://dx.doi.org/10.1080/10683160701770070

Faris, R., \& Ennett, S. (2012). Adolescent aggression: The role of peer group status motives, peer aggression, and group characteristics. Social Networks, 34, 371-378. http://dx.doi.org/10.1016/j.socnet.2010.06.003

Gottfredson, M. R., \& Hirschi, T. (1990). A general theory of crime. California: Stanford University Press.

Grasmick, H. G., Title, C. R., Bursik, R. J., \& Ameklev, B. J. (1993). Testing the core empirical implications of Gottfredson and Hirschi's General Theory of Crime. Journal of Research in Crime and Delinquency, 30, 5-29. http://dx.doi.org/10.1177/0022427893030001002

Harris, J. R. (2000). Socialization, personality development, and the child's environment: A comment on Vendell (2000). Developmental Psychology, 36, 711-723. Retrieved from http://judithrichharris.info/tna/devps yjh.htm

Hay, C., Meldrum, R. C., \& Piquero, A. R. (2013). Negative cases in the nexus between self-control, social bonds, and delinquency. Youth Violence and Juvenile Justice, 11(1), 3-25. http://dx.doi.org/10.1177/1541 204012447959

Kemp, R. A. T., Vermulst, A. A., Finkenauer, C., Scholte, R. H. J., Overbeek, G., Rommes, E. W. M., \& Engels, R. C. M. E. (2009). Self-control and early adolescent antisocial behaviour. Journal of Early Adolescence, 29(4), 497-517. http://dx.doi.org/10.1177/0272431608324474

Kim, E. J., Namkoong, K., Ku, T., \& Kim, S. J. (2008). The relationship between online game addiction and aggression, self-control and narcissistic personality traits. European Psychiatry, 23, 212-218. http://dx.doi.org/10.1016/j.eurpsy.2007.10.010

Loeber, R., Farrington, D. P., Stouthamer-Loeber, M., \& Van Kammen, W. B. (1998). Antisocial behaviour and mental health problems: Explanatory factors in childhood and adolescence. Mawhaw, NJ: Lawrence Erlbaum.

Longshore, D., Chang, E., Hsieh, S. C., \& Messina, N., (2004). Self-control and social bonds: A combined control perspective on deviance. Crime \& Delinquency, 50(4), 542-564. http://dx.doi.org/10.1177/00111287 03260684

McGloin, J. M., \& Shermer, L. O. N (2009). Self-control and deviant peer network structure. Journal of Research in Crime and Delinquency, 46(1), 35-72. http://dx.doi.org/10.1177/0022427808326585

Michaud, P. A. (2009). Bullying: We need to increase our efforts and broaden our focus. Journal of Adolescent Health, 45, 323-325. http://dx.doi.org/10.1016/j.jadohealth.2009.07.006

Miller, H. V. (2010). If your friends jumped off of a bridge, would you do it too?: Delinquent peers and susceptibility to peer influence. Justice Quarterly, 27, 473-491. http://dx.doi.org/10.1080/0741882090321 8974

Moretti, M. M., Obsuth, I., Odgers, C. L., \& Reebye, P. (2006). Exposure to maternal vs. paternal partner violence, PTSD, and aggressive behaviour in adolescent girls and boys. Aggressive Behaviour, 32, 385-395. http://dx.doi.org/10.1002/ab.20137 
Muraven, M., \& Baumeister, R. F. (2000). Self-regulation and depletion of limited resources: Does self-control resemble a muscle? Psychological Bulletin, 126(2), 247-259. http://dx.doi.org/I0.I037//0033-2909.126.2.24

Olson, S. L., \& Hoza, B. (1993). Preschool developmental antecedents of conduct problems in children beginning school. Journal of Clinical Child Psychology, 22, 60-67. http://dx.doi.org/10.1207/s1537442 4jccp2201_6

Olweus, D. (1993). Bullying at school: What we know and what we can do. Malden, MA: Blackwell Publishing

Padilla-Walker, L. M., \& Bean, R. A. (2009). Negative and positive peer influence: Relations to positive and negative behaviours for African American, European American, and Hispanic adolescents. Journal of Adolescence, 32, 323-337. http://dx.doi.org/10.1016/j.adolescence.2008.02.003

Pardini, D. A., Loeber, R., \& Stouthamer-Loeber, M. (2005). Developmental shifts in parent and peer influences on boys' beliefs about delinquent behavior. Journal of Research on Adolescence, 15(3), 299-323. http://dx.doi.org/10.1111/j.1532-7795.2005.00098.x

Phaik-Gaika, L., Maria Chong, A., Habibah, E., \& Jegak, U. (2010). Development of antisocial behaviour. Procedia Social and Behavioural Sciences, 7(C), 383-388. http://dx.doi.org/10.1016/j.sbspro.2010.10.52

Platje, E., Vermeiren, R. R. J. M., Raine, A., Doreleijers, T. A. H., Keijsers, L. G. M. T., Branje, S. J. T., ... Jansen, L. M. C. (2013). A longitudinal biosocial study of cortisol and peer influence on the development of

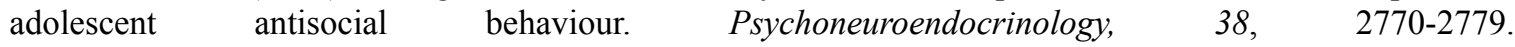
http://dx.doi.org/10.1016/j.psyneuen.2013.07.006.

Pratt, T. C., \& Cullen, F. T. (2000). The empirical status of gottfredson and Hirschi's general theory of crime: a meta-analysis. Criminology, 38, 931-964. http://dx.doi.org/10.1111/j.1745-9125.2000.tb00911.x

Proctor, L. J. (2006). Children growing up in a violent community: The role of family. Aggressive behaviour and Violent Behaviour, 11, 558-576. http://dx.doi.org/10.1016/j.avb.2005.12.004

Pulkkinen, L., Lyyra, A. L., \& Kokko, K. (2011). Is social capital a mediator between self-control and psychological and social functioning across 34 years? International Journal of Behavioral Development, 35(6), 475-481. http://dx.doi.org/10.1177/0165025411422993

Regnerus, M. D. (2002). Friends' influence on adolescent theft and minor delinquency: A developmental test of peer-reported effects. Social Science Research, 31(4), 681-705. http://dx.doi.org/10.1016/S0049-089X(02) 00010-8

Sagayam, A., \& Wong, P. M. (2010, May 25). School gangs make it hell for all. The Star. Retrieved from http://thestar.com.my/news/story.asp?file=/2010/5/25/starprobe/6332643\&sec=starprobe

Shaffer, D. R. (2005). Social and personality development (5th ed.). CA: Thomson Wadsworth.

Sheehan, M. J., \& Watson, M. W. (2008). Reciprocal influence between maternal discipline technique and aggressive behaviour in children and adolescents. Aggressive Behaviour, 34, 245-255. http://dx.doi.org/10. 1002/ab.20241

Simons-Morton, B. G., Hartos, J. L., \& Haynie, D. L. (2004). Prospective analysis of peer and parent influences on minor aggressive behaviour among early adolescents. Health Education and Behaviour, 31(1), 22-33. http://dx.doi.org/10.1177/1090198103258850

Steketee, M. (2011). The lifestyles of youth and their peers. In J. Junger-Tas, I. H. Marshall, D. Enzmann, M. Killias, \& B. Gruszcynska (Eds.), The many faces of youth crime: Contrasting theoretical perspectives on juvenile delinquency across countries and cultures (pp. 237-255). Utrecht, The Netherlands: Springer. Retrieved from http://www.generalfiles.biz/download/gs4d1a7bflh32i0/Chapter\%209\%20\%20\%20The\%20 Lifestyles\%20of\%20Youth\%20and\%20Their\%20Peers.pdf.html

Steinberg, L., \& Monahan, K. C. (2007). Age differences in resistance to peer influence. Developmental Psychology, 43, 1531-1543. http://dx.doi.org/10.1037/0012-1649.43.6.1531

Stuart, G. L., \& Holtzworth-Munroe, A. (2005). Testing a theoretical model of the relationship between impulsivity, mediating variables, and husband violence. Journal of Family Violence, 20, 291-303. http://dx.doi.org/10.1007/s10896-005-6605-6

Sullivan, T. N., Farrell, A. D., \& Kliewer, W. (2006). Peer victimization in early adolescence: Association between physical and relational victimization and drug use, aggressive behaviour, and delinquent behaviours among urban middle school students. Development and Psychopathology, 18, 119-137. 
http://dx.doi.org/10.10170/S095457940606007X

Tangney, J. P., Baumeister, R. F., \& Boone, A. L. (2004). High self-control predicts good adjustment, less pathology, better grades, and interpersonal success. Journal of Personality, 72(2), 271-324. http://dx.doi.org/10.1111/j.0022-3506.2004.00263.x

Yarbrough, A., Jones, S., Sullivan, C., Sellers, C., \& Cochran, J. (2012). Social learning and self-control: assessing the moderating potential of criminal propensity. International Journal of Offender Therapy and Comparative Criminology, 56(2), 191-202. http://dx.doi.org/10.1177/0306624X10396041

West, D. J., \& Farrington, D. P. (1977). The delinquent way of life. London: Heinemann

Winstok, Z. (2009). From self-control capabilities and the need to control others to proactive and reactive aggressive behaviour among adolescents. Journal of Adolescence, 32, 455-466. http://dx.doi.org/1016/j. adolescence.2008.08.006

Veera Pandiyan, M. (2010, July 1). Get tough on bullies. The Star. Retrieved from http://thestar.com.my/news/ story.asp?file $=/ 2010 / 7 / 1 /$ focus $/ 6580958 \&$ sec $=$ focus

\section{Copyrights}

Copyright for this article is retained by the author(s), with first publication rights granted to the journal.

This is an open-access article distributed under the terms and conditions of the Creative Commons Attribution license (http://creativecommons.org/licenses/by/3.0/). 